\title{
Detection of infectious spleen and kidney necrosis virus (ISKNV) and turbot reddish body iridovirus (TRBIV) from archival ornamental fish samples
}

\author{
J. Go ${ }^{1,8}$, T. B. Waltzek ${ }^{2}$, K. Subramaniam ${ }^{2}$, S. C. Yun $^{3}$, J. M. Groff ${ }^{4}$, I. G. Anderson ${ }^{5}$, \\ R. Chong ${ }^{5}$, I. Shirley ${ }^{6}$, J. C. L. Schuh ${ }^{6,9}$, J. H. Handlinger ${ }^{7}$, A. Tweedie ${ }^{1}$, \\ R. J. Whittington ${ }^{1, *}$ \\ ${ }^{1}$ Faculty of Veterinary Science, University of Sydney, NSW 2570, Australia \\ ${ }^{2}$ Department of Infectious Diseases and Pathology, College of Veterinary Medicine, University of Florida, Gainesville, \\ FL 32608, USA \\ ${ }^{3}$ Department of Medicine and Epidemiology, Veterinary Teaching Hospital, School of Veterinary Medicine, \\ University of California, Davis, CA 95616, USA \\ ${ }^{4}$ Department of Pathology, Veterinary Teaching Hospital, School of Veterinary Medicine, University of California, Davis, \\ CA 95616, USA \\ ${ }^{5}$ Queensland Department of Agriculture, Fisheries and Forestry (QDAFF), Biosecurity Sciences Laboratory, \\ Health and Food Sciences Precinct, Coopers Plains, QLD 4108, Australia \\ ${ }^{6}$ Department of Veterinary Pathology, Western College of Veterinary Medicine, University of Saskatchewan, Saskatoon, \\ Saskatchewan S7N 0W0, Canada \\ ${ }^{7}$ DPIPWE Animal Health Laboratory, 165 Westbury Rd, Prospect, TAS 7250, Australia \\ ${ }^{8}$ Present address: NSW Department of Primary Industries, Elizabeth Macarthur Agricultural Institute, Menangle, NSW 2568, \\ Australia \\ ${ }^{9}$ Present address: JCL Schuh, PLLC, Bainbridge Island, WA 98110-3663, USA
}

\begin{abstract}
Although infections caused by megalocytiviruses have been reported from a wide range of finfish species for several decades, molecular characterisation of the viruses involved has been undertaken only on more recent cases. Sequence analysis of the major capsid protein and adenosine triphosphatase genes is reported here from formalin-fixed, paraffin-embedded material from 2 archival ornamental fish cases from 1986 and 1988 in conjunction with data for a range of genes from fresh frozen tissues from 5 cases obtained from 1991 through to 2010 . Turbot reddish body iridovirus (TRBIV) genotype megalocytiviruses, previously not documented in ornamental fish, were detected in samples from 1986, 1988 and 1991. In contrast, megalocytiviruses from 1996 onwards, including those characterised from 2002, 2006 and 2010 in this study, were almost indistinguishable from infectious spleen and kidney necrosis virus (ISKNV). Three of the species infected with TRBIV-like megalocytiviruses from 1986 to 1991, viz. dwarf gourami Trichogaster lalius (formerly Colisa lalia), freshwater angelfish Pterophyllum scalare and oscar Astronotus ocellatus, were infected with ISKNV genotype megalocytiviruses from 2002 to 2010. The detection of a TRBIV genotype isolate in ornamental fish from 1986 represents the index case, confirmed by molecular sequence data, for the genus Megalocytivirus.
\end{abstract}

KEY WORDS: Megalocytivirus · Iridovirus - Phylogenetics · Molecular epidemiology · Ornamental fish · ISKNV · TRBIV · Red seabream iridovirus · RSIV · Taxonomy 


\section{INTRODUCTION}

Confirmed and unconfirmed cases of infections by megalocytiviruses have been reported for several decades from a wide range of ornamental and food fish including freshwater and marine species. Typical pathological changes include the presence of enlarged, often basophilic, inclusion body-bearing cells (IBC; Miyazaki 2007) and polygonal virions within these affected cells. However, while such features have been considered to be pathognomonic for megalocytivirus infections (Mahardika et al. 2009, Chinchar 2011, Sano et al. 2011), histopathology does not provide information on the genotype of megalocytivirus that may be involved. Further, the IBC can be mistaken for amoebae (Anderson et al. 1993, Stephens et al. 2009), and some authors have questioned whether some cases could be attributed to non-iridoviral viruses (Armstrong \& Ferguson 1989, McGrogan et al. 1998), all of which suggest that such lesions may not be pathognomonic. Many megalocytiviruses are difficult to isolate using cell culture, and the status of megalocytiviral taxonomy is complex and uncertain. Therefore, in the context of the following, the term 'isolate' is defined as any megalocytivirus sampled from a fish with megalocytiviral infection, rather than in the strict sense of being isolated in pure culture.

Many of the 'megalocytivirus-like' cases documented in the literature pre-date the first confirmed detection of megalocytiviruses, with the most commonly accepted index case being that described by Inouye et al. (1992) from epizootics in cultured red sea bream off Shikoku Island, Japan, during 1990 (Chinchar 2011, Kurita \& Nakajima 2012). Furthermore, all megalocytivirus isolates derived from ornamental fish species that have been subjected to phylogenetic analyses of the major capsid protein (MCP) gene have been shown to be members of the infectious spleen and kidney necrosis (ISKNV) subgroup (Sudthongkong et al. 2002b, Go et al. 2006, Jeong et al. 2008, Song et al. 2008, Weber et al. 2009, Kurita \& Nakajima 2012, Sriwanayos et al. 2013, Nolan et al. 2015). A potential exception has been recorded in African lampeyes, in which the sequence of the adenosine triphosphatase (ATPase) gene of African lampeye iridovirus (ALIV) appears to cluster with red seabream-like megalocytivirus isolates even though phylogenetic analysis of the MCP gene sequence places this isolate firmly as a member of the ISKNV subgroup (Sudthongkong et al. 2002b, Kurita \& Nakajima 2012). The third major megalocytiviral genotype comprising turbot reddish body iridovirus (TRBIV)-like isolates are believed to mainly affect flatfishes, such as flounder and turbot
(Shuang et al. 2013), although some isolates have also been reported from barred knifejaw (Kurita \& Nakajima 2012), but have not yet been described from ornamental fish.

Many reports of megalocytivirus infection involve ornamental fish, and a large proportion of these viruses have not been characterised at a molecular level (Yanong \& Waltzek 2010). It is therefore unknown whether they belong to the ISKNV or red seabream iridovirus (RSIV) subgroup, or are phylogenetically distinct. Molecular information would be useful for source attribution, to verify index cases, and to confirm whether viruses other than megalocytiviruses are capable of producing 'megalocytivirus-like' lesions.

The aim of the study was to undertake molecular epidemiological characterisation of the megalocytivirus(es) involved in ornamental fish cases identified through a literature review using archival tissues.

\section{MATERIALS AND METHODS}

\section{Case selection}

A literature review of documented cases of ornamental fish showing 'megalocytivirus-like' lesions was undertaken, focussing on those that have not previously been characterised by molecular genetic analysis. Initially, the search term 'fish*' and 'iri-

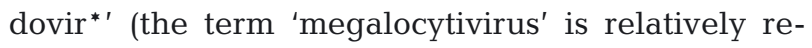
cent in origin, and hence was not used in searches for archival references) were used in the Web of Science and Aquatic Sciences and Fisheries Abstracts databases, and all references to non-food fish species involving iridoviral infection other than ranavirus or lymphocystivirus infection were further screened for pathological descriptions. References to additional cases with megalocytivirus-like lesions that were cited within those studies were also subsequently obtained. Cases known to have used acidic fixatives such as Bouin's or acidic decalcification agents such as formic acid, both of which are likely to significantly damage nucleic acids in fixed materials (Alers et al. 1999, Jones et al. 2003), were excluded.

Fresh frozen materials with preliminary evidence to suggest iridoviral infection and/or megalocytiviruslike lesions were also available from 3 previously unpublished cases, and were included in this analysis. The first 2 of these cases (Cases 3 and 4 of this study) involved juvenile oscars Astronotus ocellatus and keyhole cichlids Cleithacara maronii with a fork length of 3-4 cm. These were obtained from a com- 
mercial retail supplier and were originally purchased from an importer/wholesale distributor. The 2 populations of each species were separately held in quarantine for at least $2 \mathrm{wk}$ prior to transfer to $40 \mathrm{l}$ display tanks. The fish subsequently exhibited lethargy, listlessness and pallor within $2 \mathrm{wk}$ following transfer. The third unpublished case (Case 5 of this study) involved juvenile freshwater angelfish Pterophyllum scalare from a recirculating indoor ornamental fish production facility that experienced a mortality event soon after the introduction of various gourami (Trichogaster spp. and Trichopodus spp.) broodstock.

Two additional cases, involving oscars (Case 6) and dwarf gourami Trichogaster lalius (Case 7) were also included in which the histopathological findings and/or preliminary polymerase chain reaction (PCR) results suggested megalocytiviral presence, although further characterisation had not been undertaken (Whittington et al. 2009, Rimmer et al. 2012).

\section{Tissue preparation}

Formalin-fixed paraffin-embedded (FFPE) tissues

Sections used for DNA extraction were cut with a new microtome blade using methods designed to minimise contamination (Whittington et al. 1999). To reduce the likelihood of contamination between paraffin blocks through handling of material from different cases at the same time, sectioning and DNA extraction from blocks and PCR amplification from different cases were temporally separated.

Extraction of crude DNA from FFPE tissues was undertaken following incubation in a lysis buffer solution. A $500 \mu \mathrm{l}$ aliquot of lysis solution $(50 \mathrm{mM}$ Tris$\mathrm{HCl}, \mathrm{pH} 8,20 \mathrm{mM}$ EDTA, $\mathrm{pH} 8,2 \% \mathrm{w} / \mathrm{v}$ sodium dodecyl sulphate and Proteinase $\mathrm{K}$ at a final concentration of $175 \mathrm{mg} \mathrm{ml}^{-1}$; Bello et al. 2001) was added to tubes containing two $5 \mu \mathrm{m}$ thick paraffin sections. Tubes were incubated at a temperature of $37^{\circ} \mathrm{C}$ for $48 \mathrm{~h}$ (Gilbert et al. 2007), then heated to $95^{\circ} \mathrm{C}$ for $10 \mathrm{~min}$, centrifuged at $866 \times g(10 \mathrm{~min})$ and then gradually cooled. The supernatant solution was transferred to a new $1.5 \mathrm{ml}$ Eppendorf tube. Negative controls consisting of lysis buffer and Proteinase K solution only were also included in each extraction attempt.

\section{Fresh frozen tissues}

Tissue homogenates from megalocytivirus-like cases reported from Australia were prepared by grinding approximately $0.1 \mathrm{~g}$ pooled visceral organs in 9 volumes of minimum essential medium (MEM), which was subsequently clarified by centrifugation at $866 \times g(10 \mathrm{~min})$.

Virus isolation from oscar and keyhole cichlids

Visceral tissues (kidney, liver and spleen) were collected from moribund or dead fish and diluted 1:25 in MEM supplemented with $2 \mathrm{mM}$ L-glutamine, $2 \%$ foetal bovine serum, $50 \mathrm{IU}$ penicillin-50 $\mu \mathrm{g}$ streptomycin $\mathrm{ml}^{-1}$, and $15 \mathrm{mM}$ HEPES buffer (MEM2+HEPES). Tissues were homogenised using a Stomacher 80 Lab Blender for 1 min and centrifuged at $1300 \times g(15 \mathrm{~min})$. Supernatant was collected and diluted 1:1 with MEM supplemented with amphotericin-B and gentamicin. Tissue extracts were stored at $10^{\circ} \mathrm{C}$ overnight and centrifuged at $1500 \times \mathrm{g}$ (10 min); $0.2 \mathrm{ml}$ of supernatant were then inoculated onto the following fish cell lines: epithelioma papulosum cyprini (EPC) from fathead minnow Pimephales promelas, fathead minnow (FHM) and bluegill fry Lepomis macrochirus (BF-2) in replicate wells of a 12-well tissue culture dish. Plates were incubated at $20^{\circ} \mathrm{C}$ and observed for evidence of cytopathic effect (CPE) for $21 \mathrm{~d}$. All samples were subcultured and observed for an additional $30 \mathrm{~d}$.

\section{Transmission electron microscopy}

Formalin-fixed visceral tissues from a moribund oscar were postfixed in $1 \%$ aqueous $\mathrm{OsO}_{4}$, dehydrated through a graded ethanol series, infiltrated and embedded in epoxy resin. Ultrathin sections (60 to $90 \mathrm{~nm}$ ) were stained with $2 \%$ uranyl acetate and lead citrate prior to examination with a Phillips EM 400 electron microscope at $80 \mathrm{kV}$.

\section{Purification of DNA}

A $200 \mu \mathrm{l}$ aliquot of crude DNA extract (for FFPE tissues) or tissue homogenate was purified using a High Pure Viral Nucleic Acid Kit (Roche) following the manufacturer's instructions to produce a final DNA solution of $50 \mu \mathrm{l}$. The concentration and purity of double stranded DNA was assessed by spectrophotometry (Nanodrop, Thermo Scientific). For cases reported from the USA, viral DNA was extracted from tissue culture fluid from BF-2 cell culture supernatant that had been stored at $-80^{\circ} \mathrm{C}$ for $21 \mathrm{yr}$, using 
a DNeasy Blood and Tissue Kit (QIAGEN) following the protocol for viruses in suspension. DNA concentration and purity were quantified as described above and stored at $4{ }^{\circ} \mathrm{C}$ until used for PCR.

\section{Real-time PCR}

\section{Screening assays}

General PCR primers used in this study are summarised in Table S1 in the Supplement, available at www.int-res.com/articles/suppl/d122p105_supp.pdf. PCR screening to detect megalocytiviral DNA was undertaken using qPCR with primers C1403/C1331 targeting a $102 \mathrm{nt}$ section of the MCP gene to enable amplification to be detected in real time and minimise risks associated with cross contamination between samples. Cycling conditions for PCR were as described by Rimmer et al. (2012), with the exception that annealing temperature was decreased from 62 to $55^{\circ} \mathrm{C}$. All real-time PCR reactions were undertaken using an Mx3000P Multiplex Quantitative PCR System (Stratagene). To further minimise the likelihood of contamination, no positive controls or plasmid standards were included during PCR amplification of archival DNA samples. However, an internal control consisting of primers targeting teleost mitochondrial 16S rDNA sequence was included. These primers were designed against an alignment of representative 16S rDNA sequences from ornamental fish species of the family Cichlidae (Astronotus ocellatus, GenBank acc. no. AP009127; Etroplus maculatus, DQ119192; Pterophyllum scalare, AY662732), Osphronemidae (Trichogaster lalius, AY763701) and Poecilidae (Xiphophorus helleri, NC_013089), and were previously found to be successful when tested against a wide range of teleost DNA samples (data not shown). Water and no-template controls were included as negative process controls in all assays. Undiluted DNA extracts and extracts diluted 1:9 in nuclease-free water were used as templates for PCR.

The success of each reaction was based on generation of a cycle threshold $(\mathrm{Ct})$ value using the SYBR Green assay combined with analysis of the melting temperature $\left(T_{\mathrm{m}}\right)$ determined by the dissociation curve to ensure approximate consistency with the predicted $T_{\mathrm{m}}$ of the amplicon as determined by the neighbour-joining method using Oligocalc (www. basic.northwestern.edu/biotools/oligocalc.html) (Kibbe 2007 ) with the respective sequence template used for initial primer design as the input. The PCR product was retained and a $2 \mu \mathrm{l}$ sample was subjected to agarose gel electrophoresis; the resulting band was compared with a known molecular size marker (Lane Marker VIII, Roche) to verify that products of the expected size had been generated.

\section{Sequence-directed assays}

For subsequent PCR reactions using primer sets specifically designed based on sequence from the material extracted from FFPE archival samples in this study, thermal cycling was undertaken as above, although the number of cycles was increased from 40 to 55 following the observation that some primer pairs produced positive reactions with a $\mathrm{Ct}$ close to 40 in preliminary reactions.

\section{Primer design}

All amplicons from screening PCRs were sequenced. A megalocytiviral sequence was defined as having a sequence identity greater than $90 \%$ compared with known megalocytivirus sequences (Waltzek et al. 2012). Specific primers were designed to span the coding regions of the MCP and ATPase genes. Wherever possible, primers were designed to produce amplicons that, after primer sequences were excluded, acted as contigs to span the coding regions of the MCP gene and ATPase. However, for the MCP gene, some of the contigs located from approximately nucleotide position 1100 onwards included the primer sequences (see 'Results'). Default parameters for Primer 3 were used with minor modifications regarding product size, primer length and output number. Suitable primer pairs were then manually selected to enable overlapping contigs to be generated to span the coding region of the MCP gene. A general target amplicon length of 100 to 120 nucleotides (nt) was chosen on the basis of preliminary results that indicated that larger amplicons could not be successfully amplified from the DNA extracted from the FFPE material

For DNA derived from recent (2002 onwards) fresh frozen tissue samples, we used previously published primers (Go et al. 2006) in pairs that enabled larger amplicons to be generated, using conventional PCR as described by Go et al. (2006) (Table S1). For DNA derived from the cell culture supernatant from the US cases, a primer pair was designed that was capable of amplifying the full-length MCP gene for novel megalocytiviruses (Table S1). The primers were developed by aligning published full genomic sequences avail- 
able for ISKNV (GenBank acc. no. NC_003494), RSIV (AB104413), large yellow croaker iridovirus (LYCIV; AY779031), orange spotted grouper iridovirus (OSGIV; AY894343) and TRIBV (GQ273492). Primer binding sites flanking the MCP gene were identified in Primer 3 using default parameters, and conventional PCR was performed as described by Waltzek et al. (2012).

\section{Post-extraction, pre-amplification/repair treatments for DNA}

A modified 'assembly PCR' protocol without primers (Stemmer et al. 1995) was applied to diluted DNA samples obtained from FFPE tissues that produced poor results on initial PCR amplification. Each reaction consisted of $200 \mu \mathrm{M}$ of each of the nucleotides dATP, dTTP, dGTP, and dCTP, PCR buffer (66.8 mM Tris- $\mathrm{HCl}, 16.6 \mathrm{mM}\left(\mathrm{NH}_{4}\right)_{2} \mathrm{SO}_{4}, 2.5 \mathrm{mM}$ $\left.\mathrm{MgCl}_{2}\right), 1.65 \mathrm{mg}$ of bovine serum albumin per $\mathrm{ml}, 2 \mathrm{U}$ of Taq polymerase and $5 \mu \mathrm{l}$ of undiluted template DNA made up to a total volume of $50 \mu \mathrm{l}$ with nuclease-free water. Cycling conditions were as described above with the modification that 55 cycles were used (Stemmer et al. 1995). To generate sufficient treated DNA for subsequent PCR reactions, 5 replicate reactions were undertaken and the resultant DNA solutions were pooled.

\section{Sequencing}

Each primary PCR product was sequenced in both the forward and reverse direction using the same primers as for PCR at least once. All reactions were performed by a commercial supplier (AGRF, Westmead, NSW, Australia) using 'BigDye' Terminator version 3.1 chemistry (Applied Biosystems) and analysed in an ABI Prism 3730 or $3730 x 1$ capillary Genetic Analyser (Applied Biosystems). Sequence and ambiguous bases were assessed and resolved, respectively, by visualisation of chromatograms using MEGA 5 (Tamura et al. 2011). Alignment and editing was performed using MEGA 5, which was also used to generate the final consensus sequence.

\section{Phylogenetic analysis}

Contigs were assembled manually in MEGA 5 (Tamura et al. 2011) by sequential alignment against megalocytivirus gene sequences in Gen-
Bank, identified by a preliminary BLAST search. Gene sequences for the MCP and ATPase genes annotated in GenBank as megalocytiviruses were used to generate initial alignments. Additionally, a partial fragment of the MCP gene sequence obtained by Gias et al. (2011) from cell culture material that originated from threespot gourami showing microscopic megalocytivirus-like lesions (Fraser et al. 1993) was manually transcribed from Fig. 1 in Gias et al. (2011), since it was not available in GenBank, and included in the alignment (after editing to remove primer sequences) of megalocytiviral MCP gene sequences. The alignment of homologous gene sequences was undertaken in MEGA 5 using the ClustalW algorithm. Duplicate sequences were removed with Elimdupes (www.hiv.lanl.gov/cgi-bin/ELIMDUPES/elimdupes. cgi) using default parameters. GenBank accessions for sequences used in the phylogenetic analysis and corresponding duplicates are listed in Tables S2 \& S3 in the Supplement.

Percentage sequence identity for individual genes or genomic regions was calculated with the assistance of Sequence Identity and Similarity (SIAS: http://imed.med.ucm.es/Tools/sias.html) using default parameters, with the exception that PID1 was selected, whereby sequence identity was calculated based on the length of the shortest sequence of a pair using a pairwise alignment.

Phylogenetic trees were constructed in MEGA 5 using the maximum likelihood method with sequence data from the MCP and the ATPase genes. Default parameters were used, with the exception that bootstrapping with 1000 bootstrap replicates was used as a test of phylogeny. Gaps and truncated sequences were manually edited from the sequence alignments. For the MCP gene, the near complete coding sequence was available for the recently described threespine stickleback iridovirus (TSIV), a more divergent megalocytivirus (Waltzek et al. 2012), so all sequences were trimmed to a final length of 1342 nucleotides to enable the MCP gene tree to include TSIV. The tree was then rooted against scale drop disease virus (SDDV), a divergent iridovirid that has affinity with the genus Megalocytivirus (de Groof et al. 2015). However, since the GenBank entry for the ATPase gene of TSIV was missing approximately the first $15 \%$ of the coding sequence, valuable information would be lost by trimming all sequences to accommodate the TSIV sequence. Consequently, the tree generated for the ATPase gene sequence was rooted only against SDDV as an outgroup. 


\section{In situ hybridisation}

To verify that the microscopic lesions observed in FFPE samples were correlated to the presence of megalocytiviral DNA, in situ hybridisation (ISH) was performed using a polynucleotide probe generated using a commercial DIG Probe Synthesis Kit (Roche Applied Sciences) with the primer pair C1330/C1331 amplified from Case 7 (DGIV10) template prepared in accordance with the manufacturer's instructions. This primer pair was predicted to be capable of amplifying a 228 nucleotide probe from a wide range of megalocytivirus templates and had been successfully used in ISH to detect ISKNV megalocytiviruses using probes amplified from either an ISKNV or RSIV template (J. Go unpubl.). Protocols for ISH were adapted from published ISH protocols (Stokes \& Burreson 1995, Lee et al. 2009). Serial sections of FFPE tissues on sialinised slides were dried at $55^{\circ} \mathrm{C}$ for $1 \mathrm{~h}$, dewaxed in xylene for $5 \mathrm{~min}$ and rehydrated in a graded ethanol series with a final rinse in Milli-Q water. A $100 \mu \mathrm{l}$ solution of Proteinase K $\left(10 \mu \mathrm{g} \mathrm{ml}^{-1}\right)$ was added to each slide which was covered with parafilm and incubated at $37^{\circ} \mathrm{C}$ for $30 \mathrm{~min}$ in a humidified chamber. After Proteinase K digestion, sections were washed in Tris buffer $(\mathrm{TB} ; 0.1 \mathrm{M}$, $\mathrm{pH}$ 8.0) for $3 \mathrm{~min}$. Excess TB was removed and $100 \mu \mathrm{l}$ of pre-hybridisation buffer (50\% formamide, $10 \%$ dextran sulfate, $4 \times$ standard saline sodium citrate, $250 \mathrm{mg} \mathrm{ml}^{-1}$ yeast tRNA, $1 \times$ Denhart's solution) were added to each section. Sections were covered with parafilm and incubated in a humidified chamber for $60 \mathrm{~min}$, blotted to remove excess pre-hybridisation buffer, which was replaced with $100 \mu \mathrm{l}$ of hybridisation buffer containing $20 \mathrm{ng}$ of polynucleotide probe. Slides were covered and heated to $95^{\circ} \mathrm{C}$ for $5 \mathrm{~min}$ and then rapidly cooled by transferring slides onto ice for $5 \mathrm{~min}$. Slides were then transferred to a humidified chamber and incubated at $42^{\circ} \mathrm{C}$ overnight.

The following morning, excess hybridisation buffer was removed and the sections were washed for 10 min at $40^{\circ} \mathrm{C}$ in wash buffer (DIG Wash and Block Buffer Set ${ }^{\mathrm{TM}}$; Roche). Sections were drained and then overlaid with $500 \mu$ l blocking solution, prepared fresh according to the manufacturer's instructions (DIG Wash and Block Buffer Set ${ }^{\mathrm{TM}}$; Roche) and incubated for $30 \mathrm{~min}$ at room temperature (RT). After incubation, blocking solution was replaced with $100 \mu \mathrm{l}$ anti-DIG antibody solution consisting of sheep anti-digoxigenin antibody conjugated with alkaline phosphatase (Roche) diluted 1:200 in blocking solution. Sections were covered and incubated in a humidified chamber in the dark for 60 min at RT, rinsed in wash buffer for $30 \mathrm{~min}$ at RT and equilibrated with $500 \mu$ l detection buffer (DIG Wash and Block Buffer Set ${ }^{\mathrm{TM}}$; Roche) for 5 min. Detection buffer was drained and replaced with $500 \mu \mathrm{l}$ BCIP/NBT substrate (200 $\mu \mathrm{l}$ NBT/BCIP stock solution [Roche] in $10 \mathrm{ml}$ detection buffer) and the sections placed in a humidified chamber in the dark and incubated for 4 to $5 \mathrm{~h}$ before rinsing in Milli-Q water. Slides were air dried before examination. For long-term storage, slides were mounted with aqueous mounting media (Faramount, Dako).

Positive controls included sections of tissues from Murray cod that had been experimentally infected with dwarf gourami iridovirus (DGIV) followed by confirmation of presence of megalocytiviral DNA by qPCR (Rimmer et al. 2012); negative controls included sections from the same ornamental fish tissues that were being tested and hybridised with prehybridisation buffer without labelled probe, and Murray cod tissues that did not test positive using a qPCR assay for megalocytiviruses (Rimmer et al. 2012).

\section{RESULTS}

\section{Case material}

We identified 14 unique studies in which 13 species of finfish were reported with megalocytivirus-like infection or lesions between 1864 and 2010 (the time period spanned by the Web of Science database search). However, a range of ornamental species in Singapore (Gibson-Kueh et al. 2003), as well as chromide cichlids imported into Canada (Armstrong \& Ferguson 1989) were not considered suitable due to the use of acid-fixation and/or acidic decalcification. Of the remaining cases, all of those reported by Paperna et al. (2001) were no longer available due to the disposal and destruction of the entire archived collection following the death of Professor Paperna (A. Diamant pers. comm.). Moreove, the tissues from the ram cichlid case reported by Leibovitz \& Riis (1980) could not be located following the death of Dr. Leibovitz and the retirement of Professor Riis, despite intense efforts by a graduate student and histology technician who had worked directly with Professor Riis at Cornell University where the study was originally undertaken (E. Cornwell \& M. L. Norman pers. comm.). Materials from various ornamental fish cases reported from Florida (Fraser et al. 1993, Klinger et al. 1996, Petty \& Fraser 2005, Weber et al. 2009, 
Yanong \& Waltzek 2010) were not available due to ongoing collaborative projects between the custodians of those samples with other megalocytivirus researchers (R. Francis-Floyd \& R. Yanong pers. comm.). Material from a megalocytivirus-like outbreak in freshwater angelfish in the UK (Rodger et al. 1997) could not be retrieved due to off-site storage in a long-term archival facility (D. Faichney pers comm.). The results from the literature review for cases with megalocytivirus-like lesions are summarised in Table 1. Cases and materials used in this study are summarised in Table 2. FFPE tissues were obtained from 2 published 'megalocytivirus-like' cases. For Case 1 there appeared to be very little tissue in the paraffin block, other than a portion of the eye and some residual skin. Case 2 comprised a single block containing tissues from a single FFPE gourami (Anderson et al. 1993). Cases 3 through to 7 comprised fresh frozen materials.

\section{Preliminary PCR and sequencing results}

Extraction of DNA from FFPE tissues produced quantifiable amounts of DNA, and PCR amplification using internal control primers verified the presence of host fish DNA. Samples from Cases 1 and 2 (undiluted and 1 in 10 dilution) tested positive by qPCR using the primer pair C1403/C1331, and all controls, including process controls for the DNA extraction process and Milli-Q water no-template controls, were negative.

The sequence of the C1403/C1331 amplicon from Cases 1 and 2 was consistent with megalocytiviral MCP gene. A BLASTn search revealed complete identity across the 62 nucleotides of the amplicon sequence (trimmed of primer sequence), with GenBank accession JF264352 RBIV/Tp/45/08. This accession was obtained from barred knifejaw (rock bream) fingerlings from a disease outbreak in Taiwan during 2008 that had been recently imported as larvae from Korea. The barred knifejaw isolate exhibited the greatest similarity to the TRBIV megalocytivirus isolates, in contrast to all other isolates characterised during the same study (Huang et al. 2011).

The corresponding 62-nucleotide regions spanned by C1403/C1331 for Cases 3 and 4 (the 2 cichlid cases sampled at the same time from the same facility in the USA) were identical to each other and to the sequence obtained for Cases 1 and 2 as well as JF264352 RBIV/Tp/45/08. The sequence from Cases 3 and 4 will henceforth collectively be referred to as 'South American cichlid iridovirus' (SACIV).
In contrast, sequence analysis of the C1403/C1331 amplicon from Cases 5 to 7 revealed complete identity with ISKNV.

\section{Primer design based on preliminary results}

As a result of analysis of the preliminary sequence data from the C1403/C1331 amplicon, JF264352 RBIV/Tp/45/08 was used to design primers for amplifying DNA from Cases 1 and 2. We designed 21 pairs of primers using Primer 3 with the RBIV/Tp/45/08 MCP gene sequence (GenBank accession JF264352) as an input sequence. Some amplicons could only form contigs when the primer sequence was also included. These amplicons, and the extent of primer overlap in the resultant contigs, are outlined in Table S4 in the Supplement. For the ATPase gene, 11 primer pairs were designed to span the coding sequence using RBIV/Tp/45/08 (GenBank accession JF264212) as a template (Table S5).

\section{PCR using DNA extracted from FFPE tissues}

All $21 \mathrm{MCP}$ gene primer pairs designed against the RBIV/Tp/45/08 MCP gene, as well as the 11 ATPase gene primer pairs, successfully amplified DNA extracted from Case 2. For Case 1 material, 16 of 21 MCP gene primer pairs and 8 of 11 ATPase gene primer pairs produced an amplicon when tested against untreated DNA. No improvement in amplification was observed when diluted DNA extracts were used as PCR template. All 21 MCP gene primer pairs and 11 ATPase gene primer pairs produced a detectable and sequenceable PCR product using DNA that was pre-treated with the 'assembly PCR' protocol, and generated Ct values $<35$.

\section{PCR using DNA extracted from fresh frozen tissues}

The primer designed to amplify the full-length MCP gene for the SACIV amplified target DNA to produce the correct sized band from Cases 3 and 4. All 10 primer pairs adapted from Go et al. (2006) and Go (2004) amplified target DNA to produce correctly sized amplicons from Cases 5, 6 and 7. All amplicons for all target genes produced from Cases 6 and 7 were sequenced in both the forward and reverse directions using the PCR primers and produced high-quality sequence data consistent with single isolate template. 


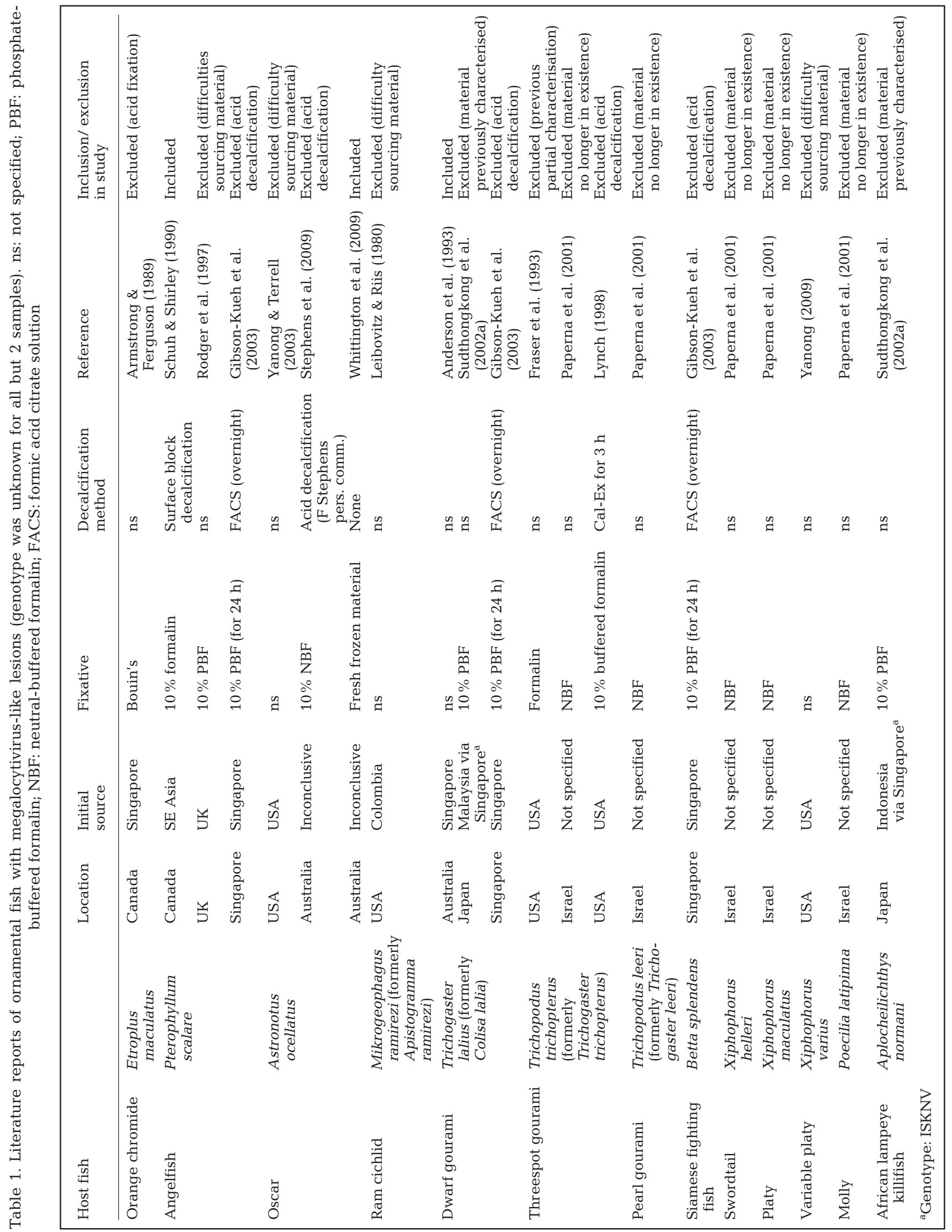




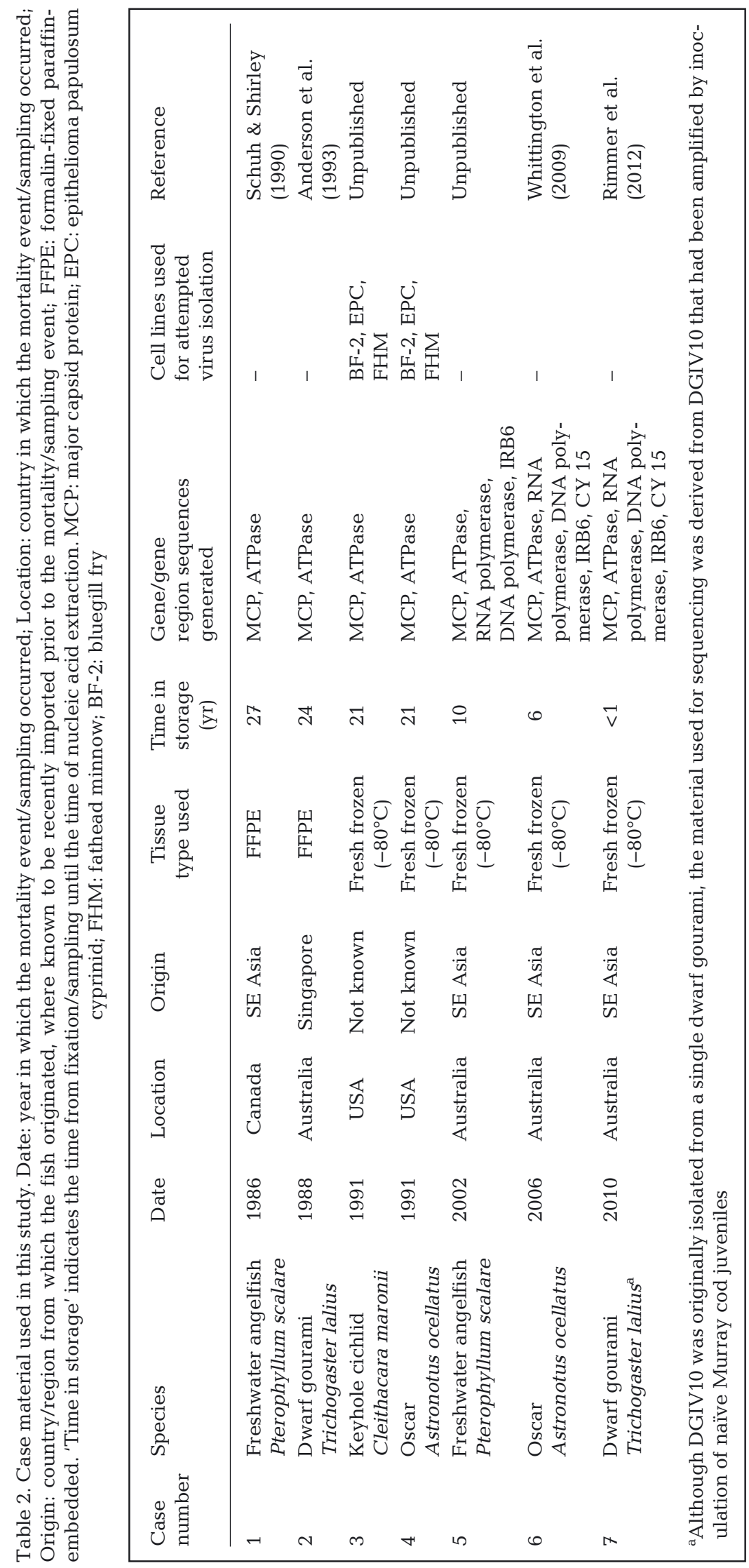

Although all amplicons from Case 5 were sequenced, this sample was potentially degraded and produced lower-quality sequence data with shorter interpretable regions of sequence for 5 reactions (MCP, ATPase and DNA polymerase genes). However, sequence consistent with single-strain template was obtained for the RNA polymerase and IRB6 genomic regions, as well as fragments from the MCP gene, ATPase gene and the region associated with the DNA polymerase.

\section{Virus isolation results}

Rounding and enlargement of occasional cells was noted at $10 \mathrm{~d}$ post inoculation with material from Cases 3 and 4 in all 3 cell lines, with BF-2 exhibiting the most severe CPE. Subculture on BF-2 cells produced CPE $6 \mathrm{~d}$ after inoculation, and continued incubation resulted in the detachment of some cells from the monolayer.

Transmission electron microscopy revealed numerous naked polygonal viral particles consistent with an iridovirus within the cytoplasm of enlarged intestinal submucosal cells (Fig. 1). The mean $( \pm \mathrm{SD})$ diameter of the complete virions was $152( \pm 10.8) \mathrm{nm}(\mathrm{n}=20)$ for opposite vertices and $137( \pm 10.2) \mathrm{nm}(\mathrm{n}=20)$ from opposite faces.

\section{Sequence alignments and phylogenetic analysis}

The percentage identity between the assembled nucleotide sequences and inferred amino acid sequences from this study were compared with representative megalocytivirus sequences (Figs. S1-S6 in the Supplement). The MCP gene nucleotide sequence derived from Case 2, referred to here as Trichogaster lalius megalocytivirus 1988 (TLMV1988), showed greatest affinity to RBIV/Tp/45/08, and was identical in sequence with Case 1, referred to here as Pterophyllum scalare megalocytivirus 1986 (PSMV1986), and with Cases 3 and 4 (SACIV). The ATPase 


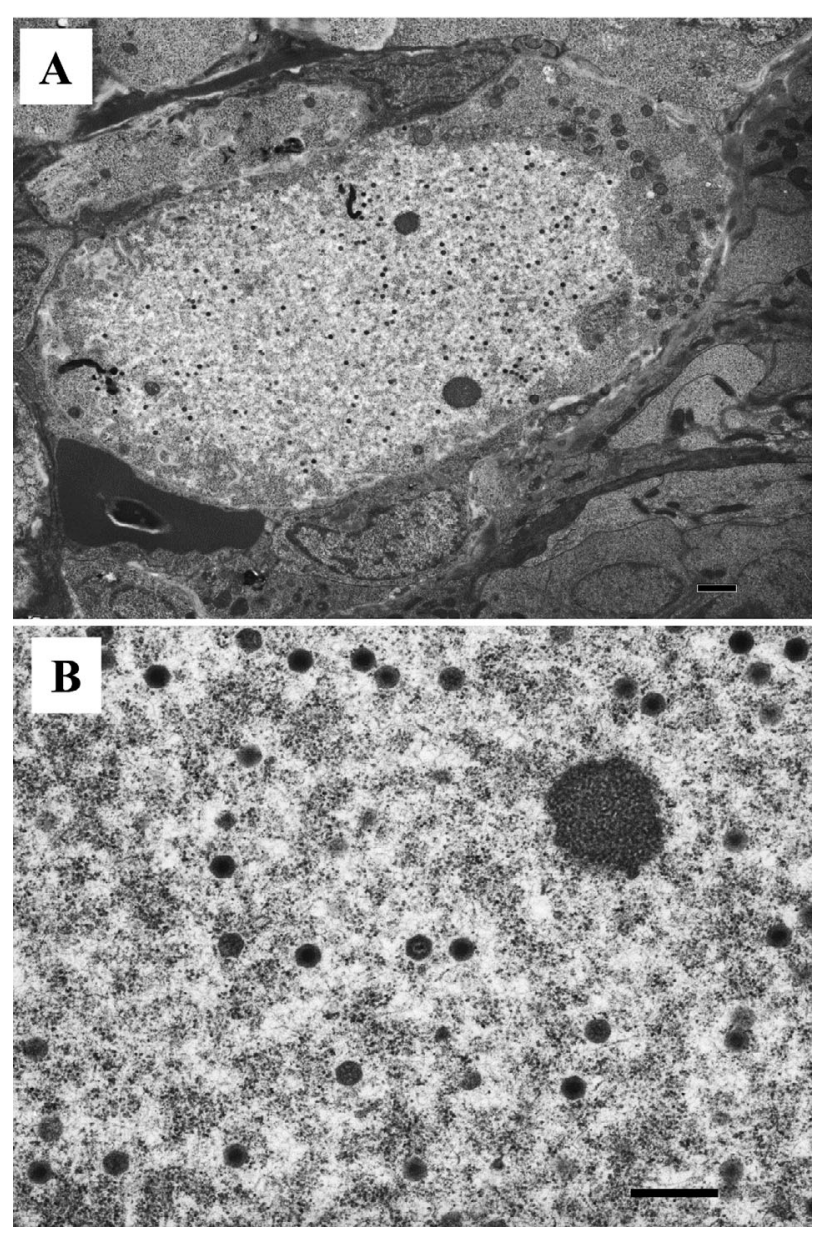

Fig. 1. (A) Transmission electron photomicrograph of the intestinal submucosa of an oscar Astronotus ocellatus (Case 4) infected with South American cichlid iridovirus (SACIV). An enlarged cell contains numerous polygonal viral particles within the cytoplasm. Scale bar $=1 \mu \mathrm{m}$. (B) Higher magnification of naked icosahedral virions with electron-dense nucleic acid core surrounded by a translucent zone and outer nucleocapsid layer. Scale bar $=500 \mathrm{~nm}$

gene sequences similarly showed a high level of identity between RBIV/Tp/45/08 and the megalocytiviruses in Cases 1 to 4 .

The phylogenetic analysis of the complete coding sequences for the MCP and ATPase genes from the megalocytivirus isolates from Case 2 (TLMV1988), the isolate from Case 1 (PSMV1986), and Cases 3 and 4 (SACIV) revealed that all 3 isolates clustered in a distinct clade of megalocytiviruses along with RBIV/Tp/45/08 (GenBank accessions JF264352 and JF264212) which was reported from rock bream in Taiwan. This clade shows greatest affinity to the TRBIV megalocytiviruses, as demonstrated in phylogenetic trees derived from MCP and ATPase gene sequences, and likely constitutes either a subgroup of this genotype, or a closely related clade (Figs. 2 \& 3). Given that RBIV/Tp/45/08 was considered by Huang et al. (2011) to be TRBIV-like, this convention will also be followed here and this clade will be regarded as a subgroup of the TRBIV genotype, and designated as Clade 2 (Figs. 2 \& 3). Partial MCP gene sequence obtained from an outbreak of megalocytivirus disease involving threespot gouramis in Florida in 1991 and 1992 (Fraser et al. 1993, Gias et al. 2011) was identical with the sequence of all 3 newly characterised megalocytiviruses as well as RBIV/Tp/45/08 and suggests that this isolate also belongs to this TRBIV Clade 2 .

Phylogenetic analysis of sequence derived from the MCP gene, the ATPase gene, the CY15 region, the IRB6 region, the DNA polymerase and the RNA polymerase gene associated regions from Case 5 (Pterophyllum scalare megalocytivirus 2002, PSMV02), Case 6 (Astronotus ocellatus megalocytivirus 2006, AOMV06) and Case 7 (DGIV10) indicated that these 3 isolates clustered strongly with the ISKNV megalocytivirus isolates. Analysis of the percentage of identity between these isolates indicated that the sequence obtained from Case 6 (AOMV06) was indistinguishable from DGIV-2004 across all genomic regions analysed that totalled 4790 nucleotides, and possessed only 1 nucleic acid substitution in a non-coding region immediately downstream from the ATPase gene compared to Case 7 (DGIV10) (99.98\% identity between AOMV06 and DGIV10). The sequence of DGIV10 in turn differed from that of ISKNV by only 2 nucleotides, including the same nucleotide substitution downstream from the ATPase gene, as well as another non-coding nucleotide associated with the ATPase gene across a total of 6370 nucleotides $(99.97 \%$ identity between DGIV10 and ISKNV). Sequence data obtained for Case 5 (PSMV02) were also indistinguishable from DGIV2004 across a total of 3344 nucleotides.

A timeline indicating the dates of the reported outbreaks of megalocytivirus-like infections in ornamental fish is shown in Fig. 4. For confirmed megalocytivirus infections, the genotype involved is shown based on data summarised in Table 1 in conjunction with additional molecular studies of megalocytiviruses in ornamental fish including those characterised during the course of this study.

\section{In situ hybridisation}

Intense blue-black staining, consistent with positive reactions, was observed in both Cases 1 and 2 
Fig. 2. Bootstrap phylogram of unique megalocytivirus major capsid protein (MCP) gene sequences over 1341 nucleotides (excluding gaps) generated by maximum likelihood analysis rooted against threespine stickleback iridovirus (TSIV) as an outgroup. Bootstrap percentage values calculated using 1000 bootstrap replicates are shown at branch nodes; the scale bar indicates distance as a proportion of nucleic acid substitutions. Gene sequences generated in this study are shown underlined in bold: PSMV1986: Pterophyllum scalare megalocytivirus 1986 (Case 1, GenBank acc. no. KX354223); TLMV1988: Trichogaster lalius megalocytivirus 1988 (Case 2, KX354222); SACIV: South American cichlid iridovirus (Cases 3 and 4, KX354221); PSMV02: Pterophyllum scalare megalocytivirus 2002 (Case 5, KX354220); AOMV06: Astronotus ocellatus megalocytivirus 2006 (Case 6, KX354219); DGIV10: dwarf gourami iridovirus 2010 (Case 7, KX354218). Refer to Table S2 in the Supplement for full descriptions of virus sequences used in this analysis
EU315313 GSIV-K1 MCP Wen

AY894343 OSGIV MCP Lu

EU847417 BPIV-07 MCP Wang

EU847418 BPIV-08 MCP Wang

AY532608 RBIV RBIV-KOR-TY4 MCP Do

HQ263620 SFIV 724/China MCP Zhao

KC775381 ISKNV LJ2012 Dong

- AY533035 RBIV-KOR-TY2 MCP Do

AY532613 RBIV SBIV-KOR-TY MCP Do

HQ317464 ISKNV HT MCP FU

HQ317463 ISKNV HZhj MCP Fu

AY849393 RBIV CNU-1 MCP Kim

DQ198145 OFIV MCP Kim

EU847414 KGIV-05 MCP Wang

JF264347 KGIV Pt 3606 MCP Huang

JF264346 GSPIV Pt 32708 MCP Huang

AB109371 RSIV MCP Sudthongkong

AB461856 RSIV U-6 MCP Shinmoto

AY849394 RBIV-CNU-2 MCP Kim

JF264355 KGIV Pt 9606 MCP Huang

- AY532614 RBIV RFIV-KOR-TY MCP Do

- AY532612 RBIV RSIV-KOR-TY MCP DO

85 AY532610 RBIV RBIV-KOR-YS MCP Do

AY532609 RBIV RBIV-KOR-GJ MCP Do

EU847420 CPIV-05 MCP Wang

- AY532606 RBIV KOR-TY1 MCP Do

99

AY532607 RBIV RBIV-KOR-TY3 MCP Do

AY310917 SBIV MCP Sudthongkong

AY285746 GSDIV MCP Sudthongkong

AB080362 RSIV-Ehime MCP Kurita

AY779031 LYCIV MCP Ao

99 HQ317457 ISKNV XT MCP Fu

HQ317458 ISKNV XQ MCP Fu

97. HM067835 MSGIV MCP Wang

AB669096 PKIV Kurita

[AB109369 DGIV MCP Sudthongkong

AB109368 ALIV MCP Sudthongkong

94

AY285745 ALIV MCP Sudthongkong

J JF264354 GSIV Pt 84305 MCP Huang

JF264350 GSIV Pt 83605 MCP Huang

88 JF264353 GSIV Pt 11306 MCP Huang JQ253371 HGIV73 Sabah/RAA/2012 Asrazitah JQ253365 GGIV3 Sabah/RAA/2012 Asrazitah JF264356 SSBIV Pt 70305 MCP Huang JQ253366 GGIV4 Sabah/RAA/2012 Asrazitah AB666344 ISKNV DGA4/6K Cola MCP Kurita HQ317460 ISKNV QY MCP FU

AY936203 MCIV MCP GO

AF371960 ISKNV MCP He/ PSMV02 / AOMV06 / DGIV10 JQ253367 HGIV65 Sabah/RAA/2012 Asrazitah - JQ253374 BMGIV48Sabah/RAA/2012 Asrazitah JQ253369 HGIV67 Sabah/RAA/2012 Asrazitah

JQ253370 HGIV73 Sabah/RAA/2012 Asrazitah

99. JF264352 RBIV Tp 4508 MCP Huang

PSMV1986 / TLMV1988 / SACIV

AY633985 KFIV FLIV-WD2 MCP Do

- AY633986 KFIV FLIV-WD1 MCP Do

EU276417 OFLIV-1 MCP Jeong

67

AY532611 RBIV RBIV-KOR-CS MCP Do

HM596017 TIV R-603 MCP Zhao

HM067603 SPIV CH-1 MCP Jeong

7 AY590687 TRBIV MCP Shi

GQ273492 TRBIV MCP Sh

AY633987 KFIV FLIV-EJ MCP Do

AY633982 KFIV FLIV-MI MCP Do

AY661546 OFIV MCP Kim

AY633984 KFIV FLIV-YG MCP Do

AY633981 KFIV FLIV-DS2 MCP Do

AY633980 KFIV FLIV-DS1 MCP Do

AY633992 KFLIV-PH MCP Do

AY633988 KFIV FLIV-JJ MCP Do

AY633989 KFIV FLIV-JSY MCP Do

- AY633991 KFIV FLIV-JHJ MCP Do

AY633983 KFIV FLIV-SS MCP Do

HQ857785 TSIV MCP Waltzek

// NC_027778 SDDV (genome) deGroof

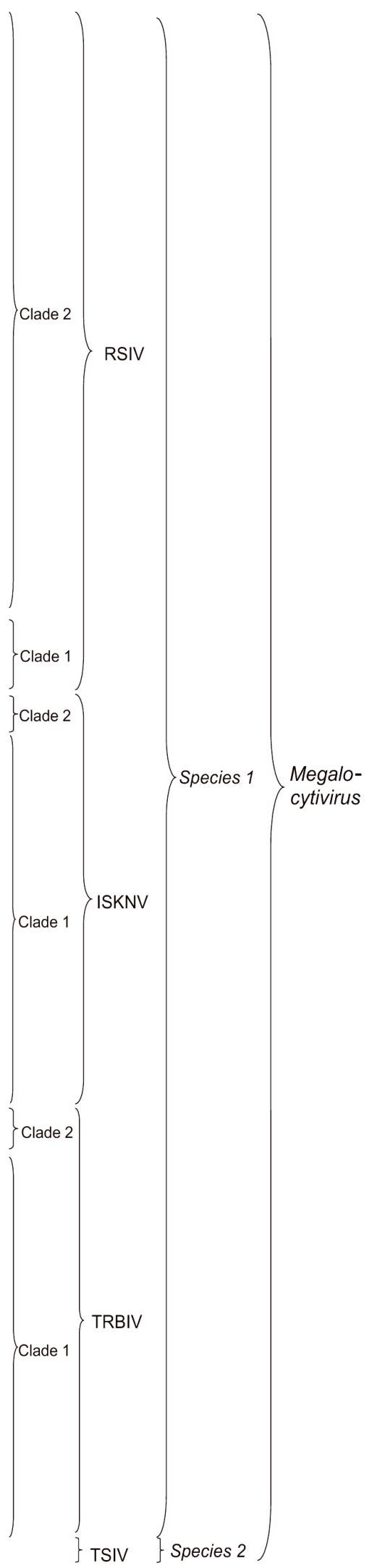




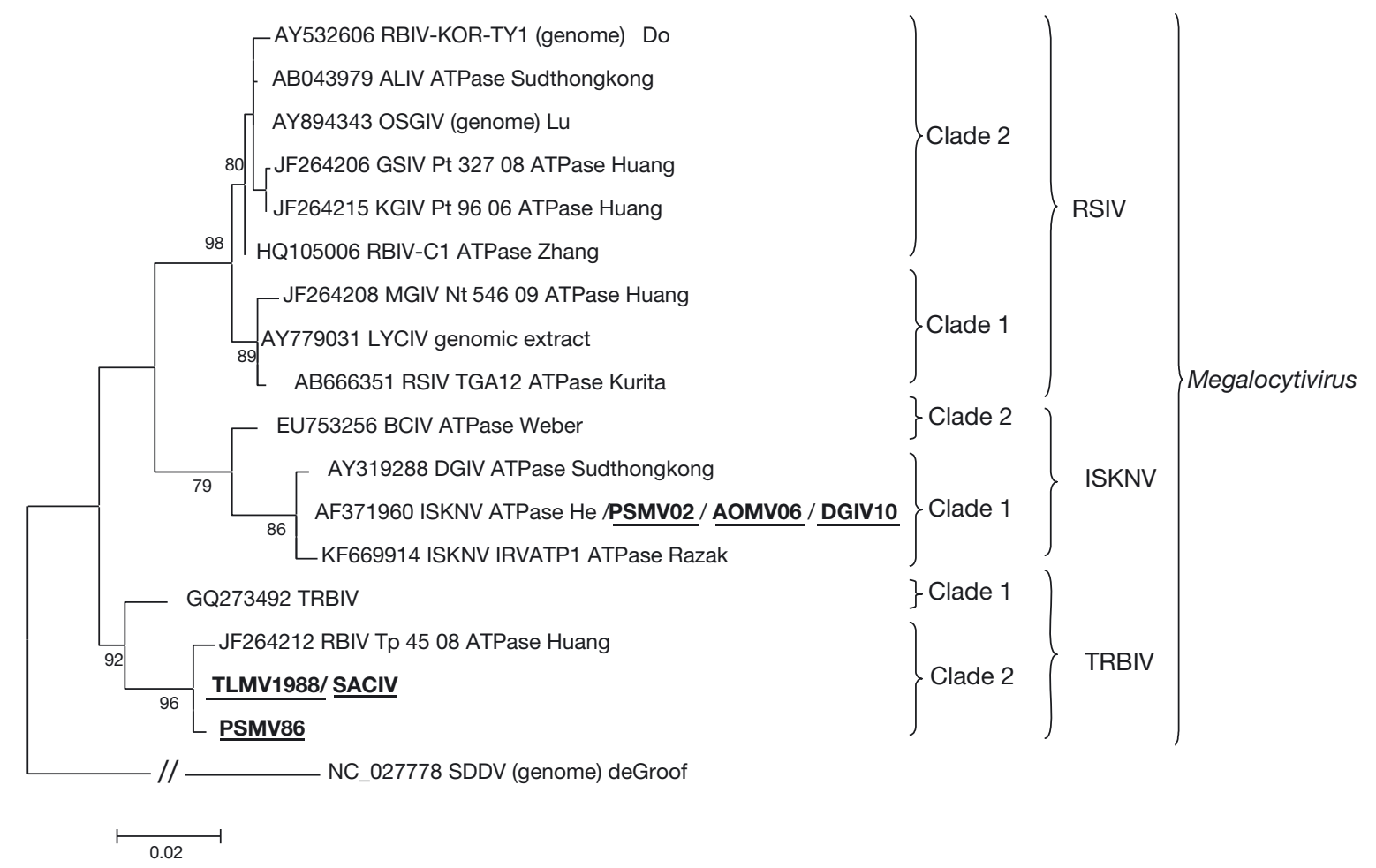

Fig. 3. Bootstrap phylogram of unique megalocytivirus ATPase gene sequences over the full-length coding region of 720 nucleotides generated by maximum likelihood analysis, rooted against scale drop disease virus (SDDV) as an outgroup. Bootstrap percentage values calculated using 1000 bootstrap replicates are shown at branch nodes; the scale bar indicates distance as a proportion of nucleic acid substitutions. Gene sequences generated in this study are shown underlined in bold (abbreviations are as defined in Fig. 2): PSMV1986 (GenBank acc. no. KX354229); TLMV1988 (KX354228); SACIV (KX354227); PSMV02 (KX354226); AOMV06 (KX354225); DGIV10 (KX354224). Refer to Table S3 in the Supplement for full descriptions of virus sequences used in this analysis

following hybridisation with the probe generated by C1330/C1331 derived from the DGIV10 template. For Case 2 (dwarf gourami), positively stained cells were abundant in many tissue types, including the renal haematopoietic tissue, intestinal lamina propria, gonadal connective tissues and heart (Fig. 5). For Case 1 (angelfish), only gill, eye and the cranial musculature was consistently present in the sections that were examined. However, low numbers of IBC were observed in the gills, which were positively stained by ISH with this probe (Fig. 6). In the serial sections stained by H\&E and hybridisation with this probe, IBC were also observed in the anterior kidney in these 2 sections. In all cases, blue-black staining was not evident in any of the control sections that were included, although brown-black endogenous melanin was sometimes present.

\section{DISCUSSION}

The results of this study enable a reassessment of index cases for megalocytivirus infection and provide the first evidence of TRBIV-like megalocytiviruses in ornamental fish species, as all previous molecular phylogenetic studies of megalocytiviruses from ornamental fish showed affinities with ISKNV (Song et al. 2008, Weber et al. 2009, Kurita \& Nakajima 2012, Sriwanayos et al. 2013, Subramaniam et al. 2014, Mohr et al. 2015, Nolan et al. 2015). To the extent that the samples analysed in this investigation are representative, the lack of detection of ISKNV megalocytiviruses in ornamental fish prior to the mid-1990s (Fig. 4) suggests that the TRBIV genotype may have been the major genotype affecting ornamental fish from the time when megalocytiviruses appeared to emerge in ornamental fish in the late 1980s until the early 1990s. This assessment is based on Case 1 (angelfish), Case 2 (dwarf gourami) and Cases 3 and 4 (oscars and keyhole cichlids) that were submitted in 1986, 1988 and 1991, respectively, and partial sequence data from the $\mathrm{MCP}$ gene of an isolate originally obtained from threespot gouramis suffering mortalities during 1991 and 1992 that were reported by Gias et al. (2011) (Fig. 4). There appear to be no records of ISKNV megalocytiviruses in the literature 


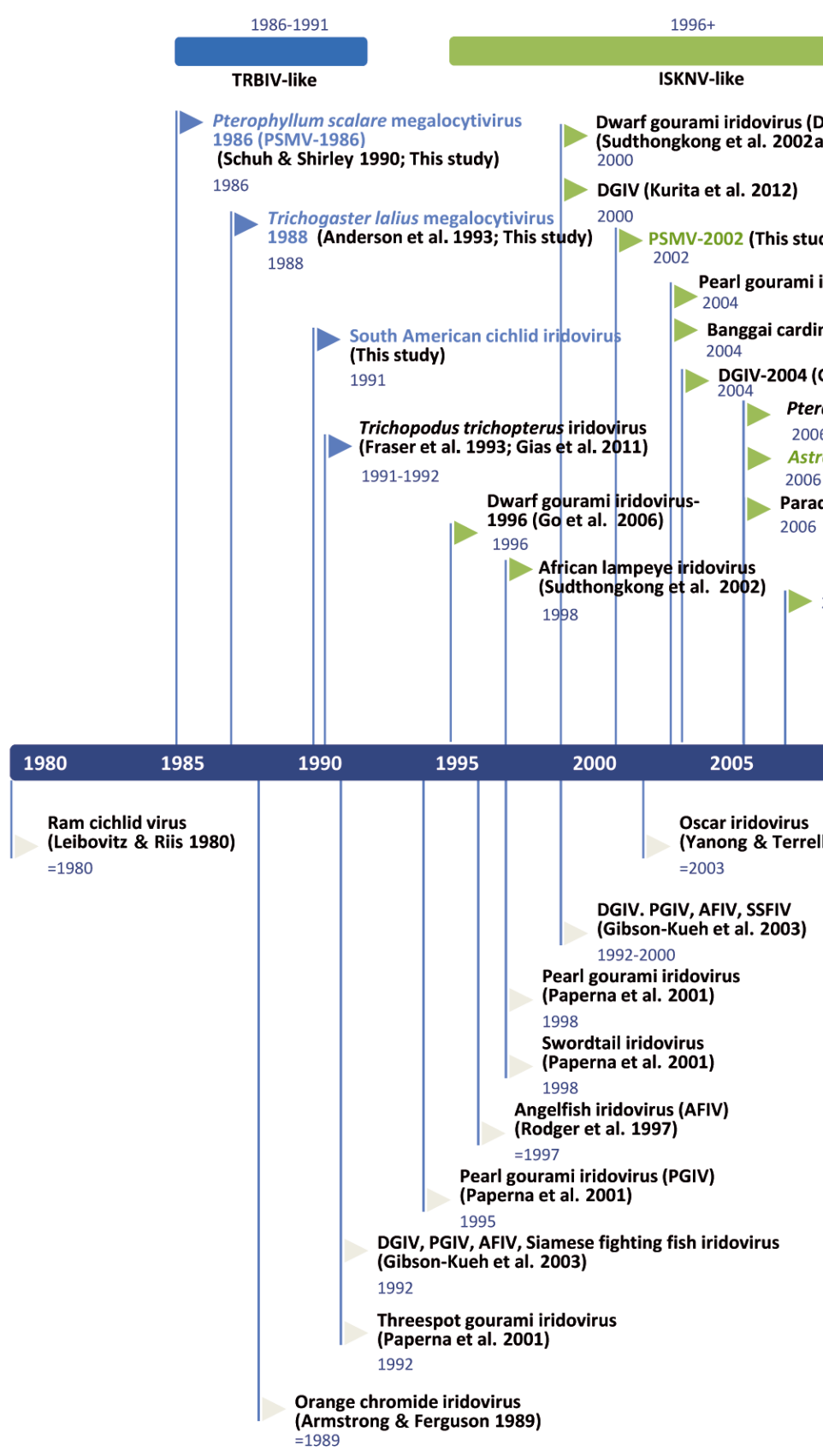

Fig. 4. Timeline of reported megalocytivirus-like infections in ornamental fish. Reports where the megalocytivirus genotype has been determined are shown above the line; uncharacterised cases are shown below the line. Megalocytiviruses characterised in this study are shown in coloured font prior to references of mandarin fish Siniperca chuatsi mortalities between 1994 and 1997. The first molecular sequence data for ISKNV were not obtained until 2001 when the entire genome for ISKNV was sequenced from mandarin fish samples collected in 1998 (He et al. 2001). However, the early literature relating to the identification of the causative agent(s) of mass mortality events in mandarin fish that were later attributed to ISKNV do not confirm that an iridovirid was involved. Some of these reports suggest involvement of a virus other than a megalocytivirus
(Zhang \& Li 1999a,b), and implicate a spherical virus, a rhabdovirus and a baculovirus (Zhang \& Li 1999b). An approximately contemporaneous outbreak occurred in dwarf gouramis imported into Melbourne, Australia, from Asia during 1996; the isolate from this case (DGIV-1996) was ISKNV (Go et al. 2006). From 1996, the ISKNV megalocytiviruses have been the only group reported from ornamental fish: DGIV and DGIV-like megalocytiviruses in dwarf gouramis and other gouramis, ALIV in African lampeye killifish (Sudthongkong et al. 2002b,a), Banggai cardinalfish 


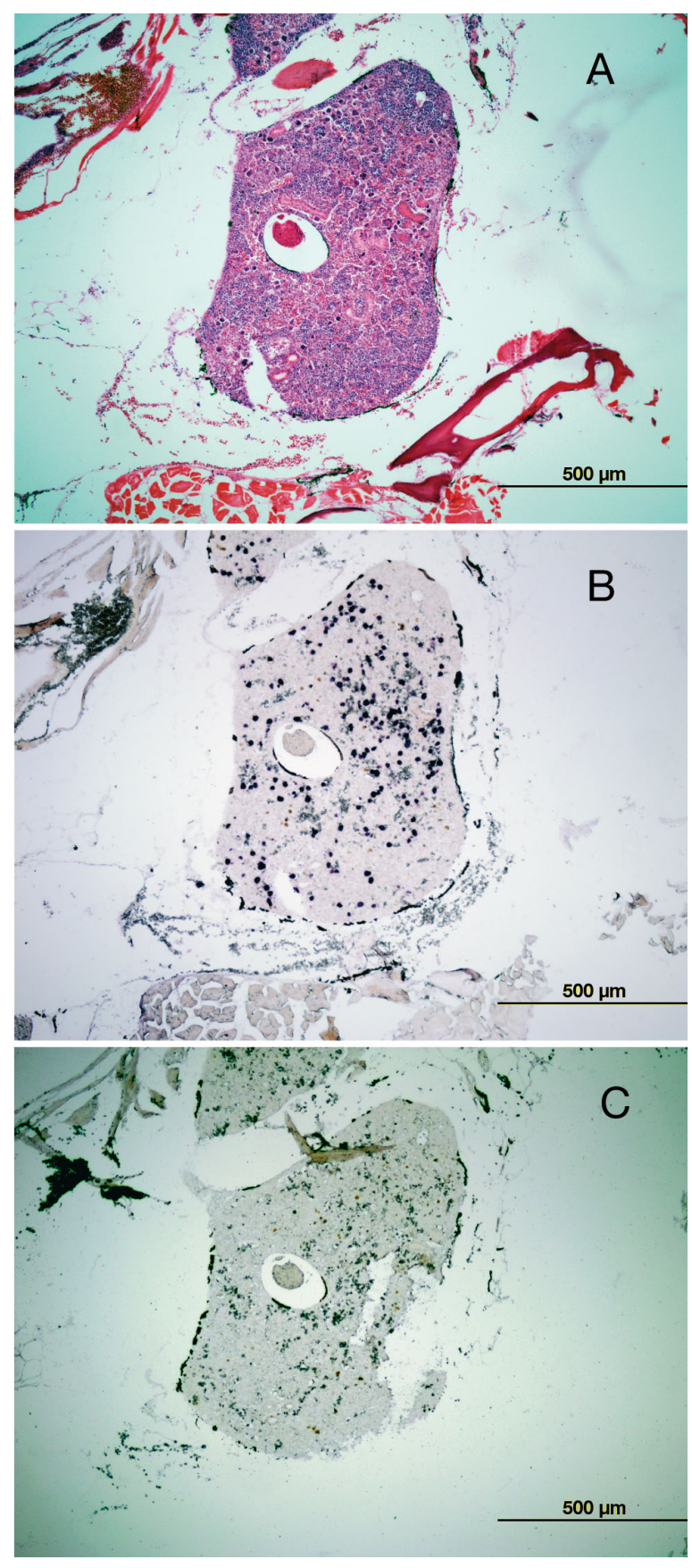

Fig. 5. Serial histological sections from archival dwarf gourami Trichogaster lalius kidney tissue (Case 2; Qld DAFF Laboratory reference 88-157132B). (A) stained with H\&E, (B) showing positive staining by digoxigenin in situ hybridisation using polynucleotide probe generated from primer pair C1330/C1331, and (C) with no probe as a control

iridovirus (BCIV)/Pterapogon kauderni iridovirus (PKIV) in Banggai cardinalfish and orbiculate batfish iridovirus (OBIV) in orbiculate batfish (Weber et al. 2009, Kurita \& Nakajima 2012, Sriwanayos et al. 2013). Parenthetically, there has been speculation as to whether ALIV from African lampeye killifish could constitute a member of the RSIV subgroup based on the inconsistency of phylogeny placement dependent on whether the MCP or ATPase gene sequences were used (Kurita \& Nakajima 2012). The characterisation of the megalocytiviral isolates from Cases 5, 6 and 7 (angelfish, oscar, dwarf gourami) as ISKNV isolates is also consistent with the view that this subgroup is currently the most commonly detected subgroup of megalocytiviruses in ornamental fish (Fig. 4).

Epizootiologically, the only record of a megalocytivirus from this specific TRBIV subtype after 1992 was from an epizootic mortality in rock bream fingerlings imported into Taiwan as larvae from Korea in 2008. This case was separated temporally (>15 yr), environmentally (marine versus freshwater) and geographically (eastern Asia versus Southeast Asia) from all other cases in which this TRBIV subtype has been detected. The origin of this TRBIV subtype is therefore unclear, given that other TRBIV isolates have generally been associated with disease outbreaks in marine flatfishes, but this subtype, prior to this detection in rock bream, was only found in freshwater ornamental fish. It is also not clear if the apparent lack of detection of this subtype of megalocytivirus in freshwater fish after 1992 is due to a lack of surveillance, true scarcity, inadequate diagnostic methods or examination of non-representative samples. If there is a true scarcity of this TRBIV subtype in current populations of ornamental fish, the reasons are also not known, but could potentially represent an evolutionary advantage for ISKNV compared with TRBIV in megalocytivirus infections of ornamental fish and would warrant further investigation.

A reassessment of the index cases for pathogenic megalocytiviruses is warranted. Regarding the occurrences of ISKNV-like megalocytivirus cases before 1996, Chao et al. (2004) mentioned that the first case of Taiwan grouper iridovirus occurred in 1980, which would make this the first recorded megalocytivirus case. However, all 3 forms of 'grouper iridovirus' (i.e. ISKNV megalocytivirus, RSIV megalocytivirus and ranavirus) have been documented from Taiwan (Huang et al. 2011), and no details were provided by Chao et al. (2004) to establish how megalocytiviral infection was confirmed, or which genotype was responsible, or whether a megalocytivirus was involved at all. Consequently, the situation in 1980 is ambiguous and cannot be confirmed as the megalocytivirus index case.

The first case of megalocytivirus infection confirmed by molecular genetic analysis is the TRBIV- 


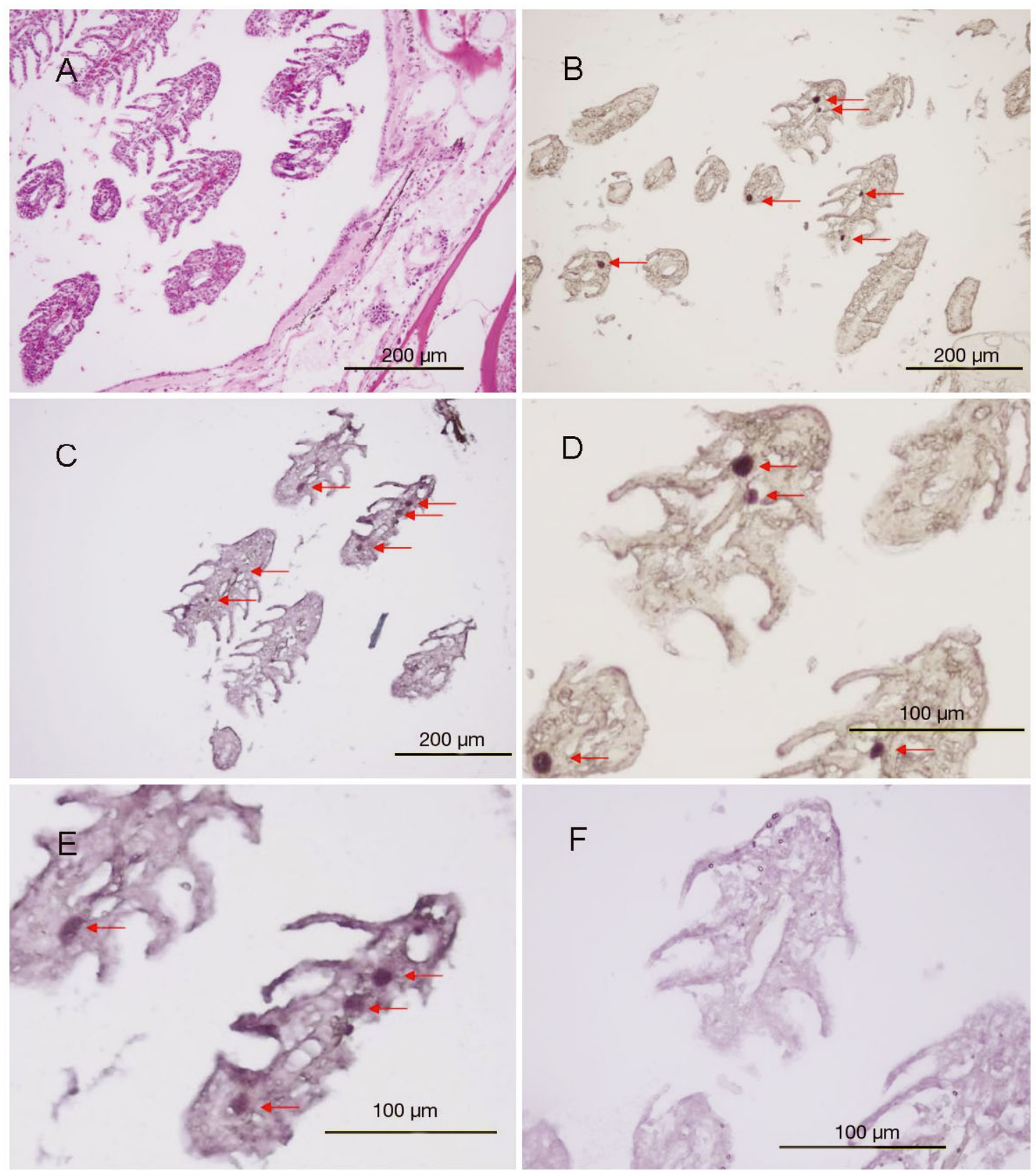

Fig. 6. Serial histological sections of archival angelfish Pterophyllum scalare gill tissue (Case 1; University of Saskatchewan Laboratory reference 86-6538) (A) stained with $\mathrm{H} \& \mathrm{E}$, and (B-E) showing positive digoxigenin in situ hybridisation using polynucleotide probes generated from primer pairs (B) C1330/C1331, (C)1324/C1325, compared with (F) no probe control sec-

tion. Panels (D) and (E) are detailed insets of panels (B) and (C), respectively. Red arrows indicate positively stained cells

like angelfish Pterophyllum scalare megalocytivirus (PSMV1986) characterised in this study (Case 1), and the first confirmed case of an ISKNV megalocytivirus is that recorded from dwarf gouramis imported to Victoria, Australia, from Asia during 1996 (Go \& Whittington 2006). Both cases involved ornamental fish, as opposed to food fish, raising the question as to whether this group of viruses may have been spread into food fish aquaculture systems through the trade in live ornamental fish. Although this mode of spread has been implicated for recent outbreaks of megalocytivirus in freshwater ornamental and food fish species (Go et al. 2006, Go \& Whittington 2006), it is not clear whether transmission of megalocytiviruses 
between freshwater ornamental species and marine food fish species is possible. Despite a study showing that a megalocytivirus from pearl gouramis (freshwater) can be pathogenic to rock bream (marine), these 2 species live in different environments and would not normally come into direct or indirect contact. There is also potential for viral transfer between freshwater and marine ornamental fish species housed in close proximity, such as in wholesale ornamental fish facilities. However, further research is required to determine whether such a transmission pathway is possible. Nonetheless, 1 subgroup, the RSIV megalocytiviruses, has not been reported in ornamental fish species, with the possible exception of ALIV in which sequence data from the ATPase gene has been shown to cluster with RSIV isolates, whereas MCP gene sequence data suggest that ALIV is an ISKNV megalocytivirus (Sudthongkong et al. 2002a,b, Kurita \& Nakajima 2012) This suggests that, even if transfer of megalocytivirus strains between ornamental and food fish can occur, it is not the only route for viral dispersal and in the case of TRBIV-like megalocytiviruses in rock bream, may have originated from other food fish species infected with TRBIV, such as olive flounder, cultured in close proximity to the rock bream. Regarding the index case for RSIV megalocytiviruses, the detection of RSIV in red sea bream in 1992 (Inouye et al. 1992) remains the index case, but the results of the current study indicate that this is not the index case for the genus Megalocytivirus as a whole.

A recurring theme in the literature is the involvement of the Asian region in megalocytivirus outbreaks of ornamental fish. In 3 of the 4 archival cases characterised in the current study, there was a recent direct link with fish imported from Southeast Asia. Specifically, megalocytiviruses were detected in dwarf gouramis in 1988 (Case 2) and oscars in 2006 (Case 6) that were held in quarantine immediately after importation from Singapore. Similarly, the angelfish in 1986 (Case 1) had also been imported from Southeast Asia. Further, the outbreak involving angelfish (Case 5) occurred after gourami broodstock, presumed to have been recently imported from Southeast Asia, were introduced into the ornamental fish culture facility. Finally, while no information was available about the origin of Cases 3 or 4, the supply of oscars into the North American ornamental fish market was dominated by fish imported from Asia, particularly Singapore and Hong Kong (Ramsey 1985, Birdsill 1988), suggesting that a link with Asia was also involved. Therefore, the results of this study provide further support for the dispersal of megalocytivirus throughout the world in association with the ornamental fish trade from Asia.

Given the apparent temporal transition between dominant genotypes of megalocytivirus in ornamental fish, it would be useful to examine more megalocytivirus-like cases, especially in the period between the early and mid-1990s, when ISKNV megalocytiviruses became the most commonly detected genotype. It is regrettable that the tissues from cases of megalocytivirus-like infection in ornamental fish from Israel during the early 1990s (Paperna et al. 2001) no longer exist. Other uncharacterised megalocytivirus-like cases (Gibson-Kueh et al. 2003) were unsuitable for examination due to the use of acid decalcification.

The only report that may pre-date the 1986 TRBIVlike megalocytivirus case in angelfish involved several consignments of ram cichlids which suffered mass mortality after importation into the USA (Leibovitz \& Riis 1980). However, the circumstances of this case are vague. Armstrong \& Ferguson (1989) and McGrogan et al. (1998) suggested it was not an iridoviral infection because the virions were not specified as polyhedral, but other authors concluded that a megalocytivirus was involved based on the presence of IBC in tissue sections (Bloch \& Larsen 1993, Chua et al. 1994, Rimmer et al. 2012, Subramaniam et al. 2012, Waltzek et al. 2012). Furthermore, the uncertain provenance of the fish makes a link with Asia difficult to confirm. The ram cichlids were submitted for diagnosis by a tropical fish retailer who had obtained the fish 1 to $3 \mathrm{~d}$ prior directly from a South American tropical fish exporter. Based on incubation periods observed experimentally (Go \& Whittington 2006) and the very short duration at the retail premises, it is likely that these fish were infected at the time of export. The majority of ram cichlids at that time were imported from Colombia, which was known to be involved in ornamental fish culture by the mid-1980s (Ramsey 1985), so it is possible that these fish may have been exposed to other fish including some of Asian origin. Without further analysis of samples, it remains unclear whether a megalocytivirus was involved. Similarly, a recent study detected ISKNV in association with altum angelfish $P$. altum recently imported from Colombia, although it is unclear in that instance whether the megalocytivirus originated from Colombia, or was introduced there from Asia (Jung-Schroers et al. 2016).

The current study is also in agreement with existing studies on megalocytivirus taxonomy and the division of the isolates, which are classified as mem- 
bers of the species Infectious spleen and kidney necrosis virus, into 3 broad genotypes with the possible exception of the clade including RBIV/Tp/45/08 and the TRBIV-like megalocytiviruses of ornamental fish characterised in this study, which could potentially form a fourth distinct genotype within the species ISKNV. However, the very recently described TSIV appears further removed from all other megalocytivirus genotypes and likely warrants classification as a novel species (Waltzek et al. 2012). Further, given the considerable scope for confusion using the term 'Infectious spleen and kidney necrosis virus' to designate either the Megalocytivirus species, the genotype or the specific isolate first described by $\mathrm{He}$ et al. (2000), we propose that this species be renamed 'Tropimegalocytivirus' in recognition of the alternate name of 'Tropivirus' that had previously been suggested as the genus name for megalocytiviruses currently classified as the species Infectious spleen and kidney necrosis virus (Sudthongkong et al. 2002b). In this case, 'Temperomegalocytivirus' could be a suitable name for the species currently represented by TSIV given the temperate origins of the host species of the latter virus. The recently described SDDV from cultured Lates calcarifer (Gibson-Kueh et al. 2012, de Groof et al. 2015) also demonstrates molecularly phylogenetic affinities with the genus Megalocytivirus, being basal to this group. However, although IBC are present in fish affected with SDDV, they are not as prevalent as in fish typically infected with viruses in the genus Megalocytivirus (Gibson-Kueh et al. 2012), and therefore this could represent a transitional form between megalocytiviruses and other iridovirids.

Our study has demonstrated that valuable taxonomic information relating to historical accounts of megalocytivirus-like infections in ornamental fish can be obtained from archival FFPE materials, something that has been recognised in various other fields (Rogers et al. 1990, Ben-Ezra et al. 1991, Greer et al. 1991, Whittington et al. 1999, Jones et al. 2003). Fixation in formalin results in fragmentation of DNA (Jones et al. 2003). Furthermore, the small size of specimens frequently necessitates the fixation of the whole fish for histological examination. This often leads to artefactual damage of the DNA because some form of decalcification of the bony tissues is often used to allow sectioning on a microtome (Noga 2000, Roberts 2012). Most commonly, acidic decalcifying agents are employed due to their rapidity and low cost but are detrimental for molecular genetic analysis (Arber et al. 1997, Alers et al. 1999, Jones et al. 2003). Therefore, to maximise utility of FFPE samples for potential molecular genetic analysis, consid- eration should be given to the use of other forms of decalcification that are less damaging to nucleic acids, such as the use of EDTA decalcification (Alers et al. 1999).

The material, particularly from Case 1 (angelfish), also highlights the potential for important molecular genetic information to be obtained from quite degraded sample material. Although superficially, very little tissue appeared to be present in the block, there was sufficient material to allow megalocytiviral DNA to be extracted with subsequent amplification of the complete gene sequences for the coding regions of both MCP and ATPase genes. Thus, by ensuring that primers were designed against short target regions of the megalocytiviral genome, it was possible to obtain phylogenetically meaningful sequence data. Similarly, it was interesting that the novel pre-treatment of attempted 'assembly PCR' was apparently successful in facilitating PCR amplification from samples that otherwise failed to amplify. While the intention had been to use the principle of 'overlap extension PCR' to allow small fragmented sequences to re-anneal and extend to form a longer stretch of DNA target suitable for the assays that were developed in this study, it is not possible to conclude that this is the mechanism by which this apparent 'DNA repair' was achieved. Other factors associated with this pre-treatment, such as repeat cycles of heating and cooling, may have assisted in the breakdown of cross-linkages or heat-labile PCR inhibitors.

This study also demonstrates that the same species of ornamental fish can be susceptible to infection with different strains of megalocytivirus, with TRBIVlike megalocytiviruses detected in freshwater angelfish, dwarf gouramis and oscars in 1986, 1988 and 1991, respectively, and ISKNV megalocytiviruses in the same species in 2002, 2010 and 2008, respectively, suggesting that these species may have a general susceptibility to megalocytiviruses.

Acknowledgements. We acknowledge assistance from Elaine Chew (Veterinary Histopathology section, Faculty of Veterinary Science, Sydney University) in preparation of sections for DNA extraction, routine histology and in situ hybridisation, and for the efforts of Emily Cornwell and Mary Lou Norman (Cornell University College of Veterinary Science) in attempting to locate the material from Leibovitz and Riis's study of ram cichlids. We also thank Anneke Rimmer for provision of DGIV10 DNA. This study was funded by the University of Sydney. J.G. acknowledges receipt of an Australian Postgraduate Award and a Vice Chancellor's research scholarship from the University of Sydney and the NSW Department of Primary Industries for granting part paid study leave to undertake this research. 


\section{LITERATURE CITED}

Alers JC, Krijtenburg PJ, Vissers KJ, van Dekken H (1999) Effect of bone decalcification procedures on DNA in situ hybridization and comparative genomic hybridization. EDTA is highly preferable to a routinely used acid decalcifier. J Histochem Cytochem 47:703-710

Anderson IG, Prior HC, Rodwell BJ, Harris GO (1993) Iridovirus-like virions in imported dwarf gourami (Colisa lalia) with systemic amoebiasis. Aust Vet J 70:66-67

Arber JM, Weiss LM, Chang KL, Battifora H, Arber DA (1997) The effect of decalcification on in situ hybridization. Mod Pathol 10:1009-1014

Armstrong RD, Ferguson HW (1989) Systemic viral disease of the chromide cichlid Etroplus maculatus. Dis Aquat Org 7:155-157

Bello N, Francino O, Sanchez A (2001) Isolation of genomic DNA from feathers. J Vet Diagn Invest 13:162-164

*Ben-Ezra J, Johnson DA, Rossi J, Cook N, Wu A (1991) Effect of fixation on the amplification of nucleic acids from paraffin-embedded material by the polymerase chain reaction. J Histochem Cytochem 39:351-354

Birdsill B (1988) Over the counter. Freshw Mar Aquar 11: 34-36

Bloch B, Larsen JL (1993) An iridovirus-like agent associated with systemic infection in cultured turbot Scophthalmus maximus fry in Denmark. Dis Aquat Org 15: 235-240

Chao CB, Chen CY, Lai YY, Lin CS, Huang HT (2004) Histological, ultrastructural, and in situ hybridization study on enlarged cells in grouper Epinephelus hybrids infected by grouper iridovirus in Taiwan (TGIV). Dis Aquat Org 58:127-142

Chinchar G (2011) Megalocytivirus. In: Tidona CA, Darai G (eds) The Springer index of viruses. Springer, New York, NY, p 763-768

* Chua FHC, Ng ML, Ng KL, Loo JJ, Wee JY (1994) Investigation of outbreaks of a novel disease, 'Sleepy Grouper Disease', affecting the brown-spotted grouper, Epinephelus tauvina Forskal. J Fish Dis 17:417-427

de Groof A, Guelen L, Deijs M, van der Wal Y and others (2015) A novel virus causes scale drop disease in Lates calcarifer. PLoS Pathog 11:e1005074

Fraser WA, Keefe TJ, Bolon B (1993) Isolation of an iridovirus from farm-raised gouramis (Trichogaster trichopterus) with fatal disease. J Vet Diagn Invest 5:250-253

Gias E, Johnston C, Keeling S, Spence RP, McDonald WL (2011) Development of real-time PCR assays for detection of megalocytiviruses in imported ornamental fish. J Fish Dis 34:609-618

Gibson-Kueh S, Netto P, Ngoh-Lim GH, Chang SF and others (2003) The pathology of systemic iridoviral disease in fish. J Comp Pathol 129:111-119

Gibson-Kueh S, Chee D, Chen J, Wang YH and others (2012) The pathology of 'scale drop syndrome' in Asian seabass, Lates calcarifer Bloch, a first description. J Fish Dis 35:19-27

Gilbert MT, Haselkorn T, Bunce M, Sanchez JJ and others (2007) The isolation of nucleic acids from fixed, paraffinembedded tissues - which methods are useful when? PLOS ONE 2:e537

Go J (2004) Impact of iridoviruses of ornamental fish for aquaculture. BSc thesis, University of Sydney

Go J, Whittington R (2006) Experimental transmission and virulence of a megalocytivirus (Family Iridoviridae) of dwarf gourami (Colisa lalia) from Asia in Murray cod (Maccullochella peelii peelii). Aust Aquacult 258: 140-149

*Go J, Lancaster M, Deece K, Dhungyel O, Whittington R (2006) The molecular epidemiology of iridovirus in Murray cod (Maccullochella peelii peelii) and dwarf gourami (Colisa lalia) from distant biogeographical regions suggests a link between trade in ornamental fish and emerging iridoviral diseases. Mol Cell Probes 20:212-222

* Greer CE, Lund JK, Manos MM (1991) PCR amplification from paraffin-embedded tissues: recommendations on fixatives for long-term storage and prospective studies. PCR Methods Appl 1:46-50

*He JG, Wang SP, Zeng K, Huang ZJ, Chan SM (2000) Systemic disease caused by an iridovirus-like agent in cultured mandarinfish, Siniperca chuatsi (Basilewsky), in China. J Fish Dis 23:219-222

*He JG, Deng M, Weng SP, Li Z and others (2001) Complete genome analysis of the mandarin fish infectious spleen and kidney necrosis iridovirus. Virology 291:126-139

*Huang SM, Tu C, Tseng CH, Huang CC, Chou CC, Kuo HC, Chang SK (2011) Genetic analysis of fish iridoviruses isolated in Taiwan during 2001-2009. Arch Virol 156: 1505-1515

* Inouye K, Yamano K, Maeno Y, Nakajima K, Matsuoka M, Wada Y, Sorimachi M (1992) Iridovirus infection of cultured red sea bream, Pagrus major. Fish Pathol 27:19-27 (in Japanese with English abstract)

Jeong JB, Kim HY, Jun LJ, Lyu JH, Park NG, Kim JK, Jeong HD (2008) Outbreaks and risks of infectious spleen and kidney necrosis virus disease in freshwater ornamental fishes. Dis Aquat Org 78:209-215

Jones SRM, Goh B, Prosperi-Porta G (2003) Duration and method of fixation affects the sensitivity of a digoxygenin-labelled DNA probe in detecting Kudoa thyrsites in Atlantic salmon skeletal muscle. Aquaculture 220: $157-164$

Jung-Schroers V, Adamek M, Wohlsein P, Wolter J, Wedekind H, Steinhagen D (2016) First outbreak of an infection with infectious spleen and kidney necrosis virus (ISKNV) in ornamental fish in Germany. Dis Aquat Org 119:239-244

Kibbe WA (2007) OligoCalc: an online oligonucleotide properties calculator. Nucleic Acids Res 35:W43-W46

*Kim WS, Oh MJ, Kim JO, Kim D, Jeon CH, Kim JH (2010) Detection of megalocytivirus from imported tropical ornamental fish, paradise fish Macropodus opercularis. Dis Aquat Org 90:235-239

Klinger RE, Francis-Floyd R, Slaughter J, Watson C (1996) Iridovirus in gouramis. University of Florida IFAS Extension Bulletin FA30. Department of Fisheries and Aquatic Sciences, Florida Cooperative Extension Service, Institute of Food and Agricultural Sciences, University of Florida, Gainesville, FL

Kurita J, Nakajima K (2012) Megalocytiviruses. Viruses 4: 521-538

Lee NS, Do JW, Park JW, Kim YC (2009) Characterization of virus distribution in rock bream (Oplegnathus fasciatus; Temminck and Schlegel) infected with megalocytivirus. J Comp Pathol 141:63-69

Leibovitz L, Riis RC (1980) A viral disease of aquarium fish. J Am Vet Med Assoc 177:414-416

Lynch MJ (1998) Preliminary investigation of gourami iridovirus infections. MSc thesis, University of Florida, Gainesville, FL 
Mahardika K, Muzaki A, Suwirya K (2009) Pathogenicity of grouper sleepy disease iridovirus (GSDIV; Megalocytivirus, family Iridoviridae) to coral trout grouper Plectrophomus leopardus. Indones Aquacult J 4:121-130

McGrogan DG, Ostland VE, Byrne PJ, Ferguson HW (1998) Systemic disease involving an iridovirus-like agent in cultured tilapia, Oreochromis niloticus L. - a case report. J Fish Dis 21:149-152

Miyazaki T (2007) Color atlas of fish histopathology, Vol 2. Shin-Suisan Shinbun-Sha, Tokyo

Mohr PG, Moody NJG, Williams LM, Hoad J, Cummins DM, Davies KR, Crane MStJ (2015) Molecular confirmation of infectious spleen and kidney necrosis virus (ISKNV) in farmed and imported ornamental fish in Australia. Dis Aquat Org 116:103-110

Noga EJ (2000) Fish diseases: diagnosis and treatment. Iowa State University Press, Iowa City, IA

Nolan D, Stephens F, Crockford M, Jones JB, Snow M (2015) Detection and characterization of viruses of the genus Megalocytivirus in ornamental fish imported into an Australian border quarantine premises: an emerging risk to national biosecurity. J Fish Dis 38:187-195

* Paperna I, Vilenkin M, Alves de Matos AP (2001) Iridovirus infections in farm-reared tropical ornamental fish. Dis Aquat Org 48:17-25

Petty BD, Fraser WA (2005) Viruses of pet fish. Vet Clin North Am Exot Anim Pract 8:67-84

Ramsey JS (1985) Sampling aquarium fishes imported by the United States. J Ala Acad Sci 56:220-245

Rimmer AE, Becker JA, Tweedie A, Whittington RJ (2012) Development of a quantitative polymerase chain reaction (qPCR) assay for the detection of dwarf gourami iridovirus (DGIV) and other megalocytiviruses and comparison with the Office International des Epizooties (OIE) reference PCR protocol. Aquaculture 358-359:155-163

Roberts RJ (2012) Laboratory methods. In: Roberts RJ (ed) Fish pathology. Blackwell Publishing, London, p 439-481

Rodger HD, Kobs M, Macartney A, Frerichs GN (1997) Systemic iridovirus infection in freshwater angelfish, Pterophyllum scalare (Lichtenstein). J Fish Dis 20:69-72

Rogers BB, Alpert LC, Hine EAS, Buffone GJ (1990) Analysis of DNA in fresh and fixed tissue by the polymerase chain-reaction. Am J Pathol 136:541-548

Sano M, Nakai T, Fijan N (2011) Viral diseases and agents of warmwater fish, In: Woo PTK, Bruno DW (eds) Fish diseases and disorders, Vol 3: Viral, bacterial and fungal infections, 2nd edn. CABI, Wallingford

Schuh JCL, Shirley IG (1990) Viral hematopoietic necrosis in an angelfish (Pterophyllum scalare). J Zoo Wildl Med 21: 95-98

Shuang F, Luo Y, Xiong XP, Weng S, Li Y, He J, Dong C (2013) Virions proteins of an RSIV-type megalocytivirus from spotted knifejaw Oplegnathus punctatus (SKIVZJ07). Virology 437:89-99

Song JY, Kitamura S, Jung SJ, Miyadai T and others (2008) Genetic variation and geographic distribution of megalocytiviruses. J Microbiol 46:29-33

Sriwanayos P, Francis-Floyd R, Stidworthy MF, Petty BD, Kelley K, Waltzek TB (2013) Megalocytivirus infection in orbiculate batfish Platax orbicularis. Dis Aquat Org 105: $1-8$

Stemmer WP, Crameri A, Ha KD, Brennan TM, Heyneker HL (1995) Single-step assembly of a gene and entire plasmid from large numbers of oligodeoxyribonucleotides. Gene 164:49-53
Stephens FJ, Jones JB, Hillier P (2009) Ornamental fish testing project: final report. Fisheries Research Division, WA Marine Research Laboratories, Perth

Stokes NA, Burreson EM (1995) A sensitive and specific DNA probe for the oyster pathogen Haplosporidium nelsoni. J Eukaryot Microbiol 42:350-357

* Subramaniam K, Shariff M, Omar AR, Hair-Bejo M (2012) Megalocytivirus infection in fish. Rev Aquacult 4:221-233

* Subramaniam K, Shariff M, Omar AR, Hair-Bejo M, Ong BL (2014) Detection and molecular characterization of infectious spleen and kidney necrosis virus from major ornamental fish breeding states in Peninsular Malaysia. J Fish Dis 37:609-618

* Sudthongkong C, Miyata M, Miyazaki T (2002a) Iridovirus disease in two ornamental tropical freshwater fishes: African lampeye and dwarf gourami. Dis Aquat Org 48: 163-173

Sudthongkong C, Miyata M, Miyazaki T (2002b) Viral DNA sequences of genes encoding the ATPase and the major capsid protein of tropical iridovirus isolates which are pathogenic to fishes in Japan, South China Sea and Southeast Asian countries. Arch Virol 147:2089-2109

Tamura K, Peterson D, Peterson N, Stecher G, Nei M, Kumar S (2011) MEGA5: molecular evolutionary genetics analysis using maximum likelihood, evolutionary distance, and maximum parsimony methods. Mol Biol Evol 28: 2731-2739

WWaltzek TB, Marty GD, Alfaro ME, Bennett WR and others (2012) Systemic iridovirus from threespine stickleback Gasterosteus aculeatus represents a new megalocytivirus species (family Iridoviridae). Dis Aquat Org 98: 41-56

*Weber ES III, Waltzek TB, Young DA, Twitchell EL and others (2009) Systemic iridovirus infection in the Banggai cardinalfish (Pterapogon kauderni Koumans 1933). J Vet Diagn Invest 21:306-320

Whittington RJ, Reddacliff L, Marsh I, Saunders V (1999) Detection of Mycobacterium avium subsp. paratuberculosis in formalin-fixed paraffin-embedded intestinal tissue by IS900 polymerase chain reaction. Aust Vet J 77: 392-397

Whittington RJ, Tweedie A, Dennis MM, Becker JA, Landos M (2009) FRDC final report Aquatic Animal Health Subprogram: optimisation of PCR tests for diagnosis of megalocytivirus (gourami iridovirus) and cyprinid herpesvirus 2 (goldfish herpesvirus) FRDC Project No. 2007/007. University of Sydney, Faculty of Veterinary Science, Camden

Yanong RPE (2009) Fish clinical cases: What's your diagnosis? In: Proc 81st Western Veterinary Conference, p v734

Yanong RPE, Terrell SP (2003) Iridoviral-associated disease in oscars (Astronotus ocellatus). In: Proc 34th Annu Conf Int Assoc Aquat Anim Med, p 81-83

Yanong RPE, Waltzek TB (2010) Megalocytivirus infections in fish, with emphasis on ornamental species. University of Florida IFAS Extension Bulletin FA182. Program in Fisheries and Aquatic Sciences, School of Forest Resources and Conservation, UF/IFAS Extension, University of Florida, Gainesville, FL

Zhang Q, Li Z (1999a) Detection of viral pathogen from diseased mandarin fish (Siniperca chuatsi) with pathological observations. Acta Hydrobiol Sin 23:151-154

Zhang QY, Li ZQ (1999b) Three different viruses observed from the tissues of diseased mandarin fish Siniperca chuatsi. Chin Sci Bull 44:437-441 